\title{
Nutritional quality of kermes oak (Quercus coccifera L.) acorns as affected by altitude in a typical Mediterranean area
}

\author{
Christos N. Roukos ${ }^{1}$, Zoi M. Parissi ${ }^{2}$, Apostolos P. Kyriazopoulos ${ }^{3}$, and Eleni M. Abraham ${ }^{2}$ \\ ${ }^{1}$ Ministry of Rural Development and Food, Regional Department of Epirus \& Western Macedonia, \\ 45110 Ioannina, Greece \\ ${ }^{2}$ Department of Forestry and Natural Environment, Aristotle University of Thessaloniki, \\ Laboratory of Range Science (236), 54124 Thessaloniki, Greece \\ ${ }^{3}$ Department of Forestry and Management of the Environment and Natural Resources, \\ Democritus University of Thrace, 193 Pantazidou str., 68200 Orestiada, Greece
}

Correspondence to: Christos N. Roukos (roukxris@gmail.com)

Received: 7 January 2017 - Revised: 13 March 2017 - Accepted: 20 March 2017 - Published: 18 April 2017

\begin{abstract}
The impact of altitudinal zone on the nutritional quality of kermes oak (Quercus coccifera L.) acorns was assessed in Xirovouni Mountain shrublands in northwestern Greece. Whole acorns were collected during autumn 2011 from 15 sites located at three altitudinal zones (i.e. lower, middle, upper). Kermes oak acorn samples were manually separated into kernel and hull and analysed for chemical composition (crude protein, CP; neutral detergent fibre, NDF; acid detergent fibre, ADF; lignin), in vitro dry matter (DM) digestibility (IVDMD), in vitro NDF digestibility (IVNDFD), digestible energy (DE), and minerals (i.e. $\mathrm{Ca}, \mathrm{P}, \mathrm{K}, \mathrm{Mg}, \mathrm{Mn}, \mathrm{Fe}, \mathrm{Zn}, \mathrm{Cu}$ ). Altitude had a negative correlation with CP, IVDMD, and IVNDFD and positively correlated to cell wall contents in both kernel and hull. Acorns growing under higher temperatures (at lower altitude) have more digestible cell wall compared to acorns growing under lower temperatures (at higher altitude) due to increased CP content and decreased cell wall content. It seems that environmental factors affect the nutritional value of acorns. Thus, goat farmers should take this into account when collecting acorns to feed their animals.
\end{abstract}

\section{Introduction}

Kermes oak (Quercus coccifera L.) is a sclerophyllous evergreen shrub that is well adapted to the Mediterranean climate (Tsiouvaras, 1987). It is the most abundant evergreen species in Greece and constitutes one of the main shrubland types that extends from lowlands to mountainous areas. Extensive goat farming plays a key role in the sustainability of these ecosystems as well as the cost-effective production of safe and high-quality animal products (Papachristou et al., 2005; Chatzitheodoridis et al., 2007).

Worldwide, goats consume not only the leaves of the oak species but also their acorns. Although the nutritional quality of kermes oak browse has been well studied (Nastis, 1982; Tsiouvaras, 1987; Sallam et al., 2010; Parissi et al., 2014;
Roukos, 2016), limited research has been conducted on factors affecting the nutritional quality of kermes oak acorns.

Acorns are the nuts of oak species and their nutritional quality is affected by the stage of maturity (Moujahed et al., 2003), which, in turn, is affected by climatic conditions (Merouani et al., 2003; Pons and Pausas, 2012). The maturation of kermes oak acorns is biennial. They usually reach their maturity by the end of autumn. For example, in Epirus, northwestern Greece, due to climatic variability (Dotsika et al., 2010) acorns are usually harvested by goat shepherds from the end of autumn until the end of winter and fed to goats during the winter. Acorns are a good source of energy for small ruminants (Kayouli and Buldgen, 2001) and they could replace $50 \%$ of the barley in goat diets (Moujahed et al., 2005) and $25 \%$ in lamb diets (Al Jassim et al., 1998). 
Moreover, they are a valuable feed in pig diets (Nieto et al., 2002).

In Greece, the economic crisis has forced goat producers to expand the use of kermes oak acorns in goat diets since no alternative cheap feedstuffs are available. Indeed, kermes oak shrublands, located in Greek mountainous and less-favoured areas, are a valuable feed resource for goats as they cover up to $75 \%$ of goats' feed requirements (Zervas, 1998), which accounts for up to $50 \%$ of goats' total production cost (Chatzitheodoridis et al., 2007).

The highly heterogeneous topography of the mountains influences local and regional microclimates by altering the patterns of climatic variables, such as rainfall and temperature (Holechek et al., 2010). There is limited information available regarding the interactions between climate and topography that lead to fluctuations in the nutritive value of kermes oak acorns and directly affect goats' productivity. Thus, the aim of the present study was to compare the nutritional quality of kermes oak acorns of shrublands located at different altitudinal zones.

\section{Materials and methods}

\subsection{Study area}

The study was conducted at Xirovouni Mountain (longitude $20.942940^{\circ}$, latitude: $39.370576^{\circ}$ ) located in Epirus in northwestern Greece from February 2010 to November 2011. The climate is typically Mediterranean, characterized by cold, rainy winters and dry, warm summers. From 1976 to 1997 , the mean annual temperature was $17.2^{\circ} \mathrm{C}$ and the mean annual precipitation was $1085 \mathrm{~mm}$ (HNMS, 2009). During the present study, an automated weather station (Onset HOBO weather station, Onset Computer Corporation, MA, USA) was installed in each altitudinal zone to record precipitation and temperature fluctuations throughout the 2 years of the experimental period (Fig. 1). Soils are calcareous, mainly sandy, with a $\mathrm{pH}$ of 7.1-7.4, and insufficient in $\mathrm{N}, \mathrm{P}$, and $\mathrm{K}$ (Roukos et al., 2011). Geologically, the plain belongs to the Ionian geotectonic zone. The basic substrates are dolomite, Viglas limestone, and flysch.

\subsection{Methods of sampling}

Representing typical kermes oak shrublands on Xirovouni Mountain, 15 sites of western-southwestern aspect were selected for sampling during February 2010. Three altitudinal zones based on altitude a.s.l. were differentiated: upper (above $1001 \mathrm{~m})$, middle (501-1000 m), and lower (0-500 m). Five experimental plots of $20 \mathrm{~m}^{2}$ were fenced in each zone to exclude grazing. Whole kermes oak acorns were hand-clip collected from at least four individual shrubs in each plot at the end of October in the lower zone, in early November in the middle zone, and in mid-November in the upper zone. A total of 100 acorns (25 acorns per shrub) per plot were ran-
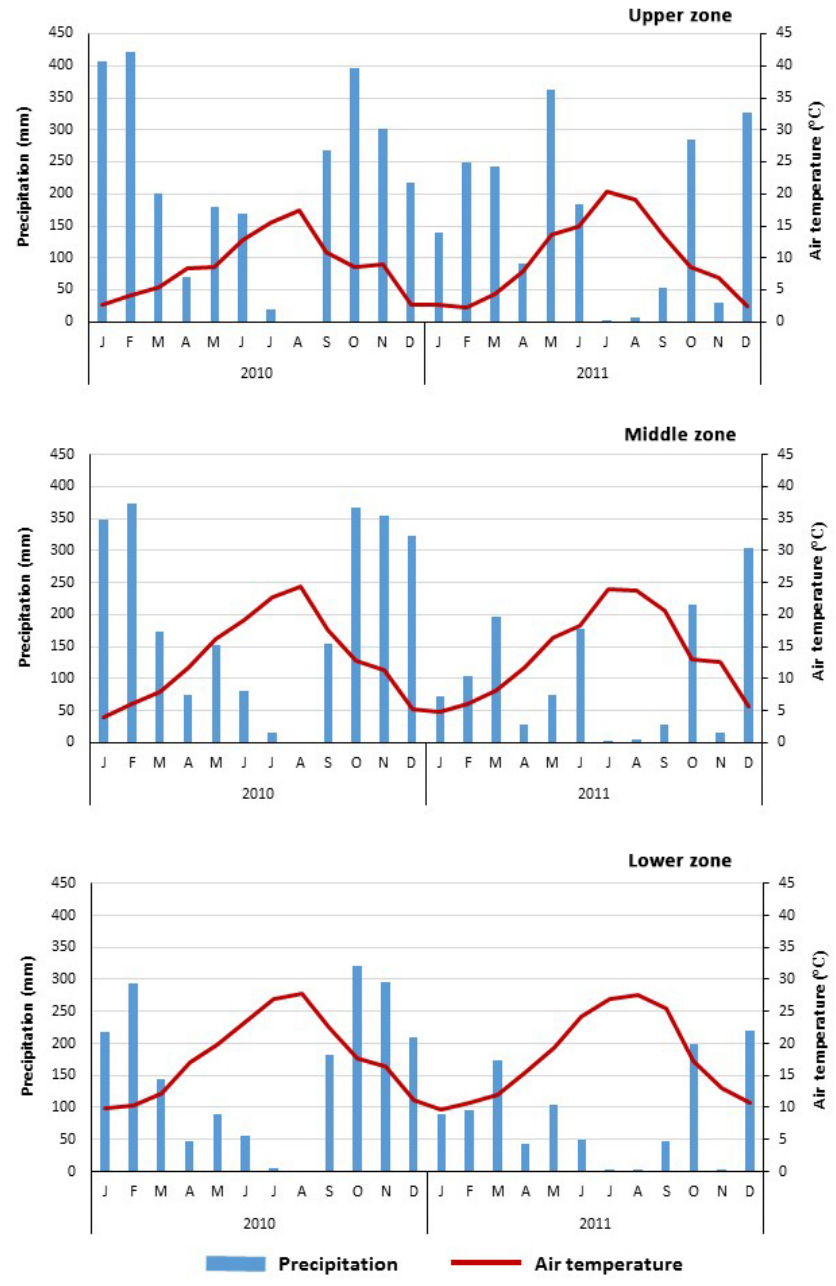

Figure 1. Fluctuations of mean air temperature and monthly precipitation during the study period in the three altitudinal zones.

domly selected. The selected acorns had the same morphological form and thus represented the same stage of maturity according to Merouani et al. (2003). The acorn samples were directly placed into individual paper bags in the field and then spread onto a tray and air-dried gradually in shade at room temperature for 2 weeks in the laboratory. Dry acorn samples were weighted after drying in an oven for $48 \mathrm{~h}$ at $50-52{ }^{\circ} \mathrm{C}$ to determine hull : whole fruit and kernel : whole fruit ratios on a dry-matter basis. The acorns were then manually separated into kernel and hull, ground with a Kinematica mill (model Polymix PX-MFC 90D) through a $1 \mathrm{~mm}$ sieve, and stored at $4{ }^{\circ} \mathrm{C}$ until further analysis.

\subsection{Analytical methods}

Analyses were performed on the acorn part sample (kernel and hull). The $\mathrm{N}$ content was determined using a Kjeldatherm KB 8 S-BS digestion unit and a Vapodest 40 distillation unit (Gerhardt, GmbH \& Co. KG, Germany) using the 
AOAC (1995) method 984.13. The ANKOM Fiber Analyzer (ANKOM Technology, Macedon, NY, USA) was used to determine the neutral detergent fibre (aNDFom) according to Van Soest et al. (1991) as modified by Vogel et al. (1999) for the ANKOM system. Heat-stable $\alpha$-amylase (A3306, SigmaAldrich, St. Louis, MO, USA) without sodium sulfite in the neutral detergent (ND) was used in the analysis of aNDFom content. The AOAC (1997) method was used to determine acid detergent fibre (ADFom). ADFom and aNDFom are expressed with correction for residual ash. The sulfuric acid procedure (AOAC, 1997; method 973.18) was used to determine lignin(s) and ash was determined as the gravimetric residue after heating to $550^{\circ} \mathrm{C}$ for $8 \mathrm{~h}$.

An ANKOM Daisy II incubator (ANKOM Technology) was used to measure in vitro dry-matter (DM) digestibility (IVDMD) according to Vogel et al. (1999). Rumen fluid was obtained from eight non-lactating local breed goats fed with kermes oak foliage, acorns, and some grain, according to their nutrient requirements. An adiabatic bomb calorimeter (IKA C5000, IKA Works, Inc, Wilmington, NC, USA) was used to measure the gross energy of each sample. Postdigestion analyses were completed on the undigested residue in order to determine the aNDFom content according to methods described above and the gross energy of the residue was determined using a bomb calorimeter.

In vitro NDF digestibility (IVNDFD) was calculated according to Hall and Mertens (2008) as

\section{$\operatorname{IVNDFD}\left(\mathrm{g} \mathrm{kg}^{-1} \mathrm{NDF}\right)=(1-$ [post-digestion dry weight}

following ND wash/pre-digestion dry weight of NDF]).

In addition, digestible energy was determined with the equation

$$
\begin{aligned}
& \mathrm{DE}\left(\mathrm{MJ} \mathrm{kg}^{-1} \mathrm{DM}\right)=(\text { pre-digestion gross energy } \\
& -[\text { gross energy in residue } \times(1-\text { IVDMD })]) .
\end{aligned}
$$

Concentrations of $\mathrm{K}, \mathrm{Ca}, \mathrm{Mg}, \mathrm{P}, \mathrm{Cu}, \mathrm{Mn}, \mathrm{Fe}$, and $\mathrm{Zn}$ in the acorn (hull and kernel) samples were evaluated by oxidizing each subsample with a $2: 1$ nitric / perchloric acid mixture. In separate aliquots, $\mathrm{Ca}$ and $\mathrm{K}$ were determined by flame photometry, $\mathrm{P}$ by spectrophotometric methods (Khalil and Manan 1990), and Fe, Mn, Zn, Cu, and Mg by atomic absorption spectrophotometry (AOAC, 1999; method 968.08) (PERKIN ELMER/AA800, PerkinElmer, Inc., San Jose, CA, USA). Each sample was analysed in triplicate. The concentrations of macronutrients and sodium were expressed in milligram per gram dry weight, while those of microelements are given in milligram per gram.

\subsection{Statistical analyses}

One-way ANOVA was carried out to determine the effect of altitude on chemical constituents, mineral contents, and nutrient digestibility of the acorns' hull and kernel. Acorns from each shrub (i.e. 25 acorns each) were bulked in order to ensure the quantity necessary for the chemical analyses. Thus, five replications per zone were used to perform the statistical analysis. The normality of the distribution was determined through the Shapiro-Wilk test. Since the samples had a normal distribution, the one-way ANOVA with least significant distance post hoc test was used. Differences were considered statistically significant at the $P<0.05$ level. Correlation between nutritive value variables, climatic variables, and altitude was measured using the Pearson correlation coefficient (Steel and Torrie, 1980). Moreover, the relationships between altitude, climatic, and nutritive value variables were tested using linear regression over average for each acorn part (kernel and hull). All analyses were conducted using IBM SPSS Statistics v. 21.0.0 (New York, USA) software.

\section{Results and discussion}

\subsection{Climatic conditions}

Climatic conditions influence the maturation stage of acorns (Vázquez et al., 2001; Ferraz de Oliveira, 2012) and, as a consequence, indirectly affect their chemical composition. In the study area, the air temperature and precipitation patterns were differentiated in the altitudinal zones (Fig. 1). Indeed, the mean monthly precipitation was positively correlated, while air temperature was negatively correlated with altitude ( $r=0.217 ; P<0.05$ and $r=-0.484 ; P<0.01$ respectively). As a result, the mean monthly air temperature progressively reduced with the increase in altitude during the experimental period. Thus, the differentiation of climatic conditions in each zone might affect the maturation of the acorns.

\subsection{Proportions of kermes oak acorns components}

The hull weight of the acorns ranged from 173 to $225 \mathrm{~g} \mathrm{~kg}^{-1}$ (Table 1) and was significantly higher in the upper zone compared to the lower one. Conversely, the weight of the acorn kernels was significantly $(P<0.05)$ lower in the upper zone compared to the lower one (Table 1 ).

\subsection{Crude protein and cell wall contents}

In general, the Quercus coccifera acorn hulls had lower crude protein (CP) content and higher cell wall content compared to the kernels (Table 2). The CP of the acorn hulls did not significantly differ among the altitudinal zones (Table 2). Inversely, the $\mathrm{CP}$ content of the kermes oak kernels was higher $(P<0.05)$ in the lower zone compared to in the middle and upper zones (Table 2). The positive correlation between $\mathrm{CP}$ and air temperature $(P<0.01, r=0.894)$ enhances the above-mentioned result. Due to climatic differences between altitudinal zones, the crude protein content declines with the decrease in air temperature, a result that is in agree- 
Table 1. Parts of kermes oak acorns $\left(\mathrm{g} \mathrm{kg}^{-1}\right)$ in the three altitudinal zones.

\begin{tabular}{|c|c|c|}
\hline \multirow[t]{3}{*}{ Altitudinal zone } & \multicolumn{2}{|c|}{ Part of acorns } \\
\hline & Kernel & Hull \\
\hline & \multicolumn{2}{|c|}{$\mathrm{g} \mathrm{kg}^{-1}$} \\
\hline Lower & $826 a^{*}$ & $173 b$ \\
\hline Middle & 789ab & $211 \mathrm{ab}$ \\
\hline Upper & $775 b$ & $225 a$ \\
\hline SEM & 21 & 15 \\
\hline
\end{tabular}

Table 2. Chemical composition of kermes oak (kernel and hull) ( $\left.\mathrm{g} \mathrm{kg}^{-1} \mathrm{DM}\right)$ according to the altitudinal zone.

\begin{tabular}{lrrrrr}
\hline \multirow{2}{*}{ Parameter } & Lower & Middle & Upper & SEM & Sig. \\
\cline { 2 - 6 } & \multicolumn{5}{c}{ Kernel } \\
\hline CP & $45.6 \mathrm{a}$ & $42.2 \mathrm{~b}$ & $39.8 \mathrm{c}$ & 0.59 & $* * *$ \\
$\mathrm{NDF}$ & $123.8 \mathrm{c}$ & $147.8 \mathrm{~b}$ & $161.0 \mathrm{a}$ & 3.77 & $* * *$ \\
$\mathrm{ADF}$ & $30.6 \mathrm{~b}$ & $27.6 \mathrm{~b}$ & $39.0 \mathrm{a}$ & 1.43 & $* * *$ \\
$\mathrm{ADL}$ & $5.4 \mathrm{~b}$ & $6.0 \mathrm{~b}$ & $7.8 \mathrm{a}$ & 0.53 & $*$ \\
\hline \multicolumn{7}{c}{ Hull } \\
\hline $\mathrm{CP}$ & $31.3 \mathrm{a}$ & $29.4 \mathrm{a}$ & $31.5 \mathrm{a}$ & 0.89 & $\mathrm{NS}$ \\
$\mathrm{NDF}$ & $622.2 \mathrm{~b}$ & $671.8 \mathrm{a}$ & $670.8 \mathrm{a}$ & 5.91 & $* * *$ \\
$\mathrm{ADF}$ & $456.2 \mathrm{~b}$ & $459.0 \mathrm{~b}$ & $473.8 \mathrm{a}$ & 4.41 & $*$ \\
$\mathrm{ADL}$ & $188.0 \mathrm{~b}$ & $194.2 \mathrm{ab}$ & $201.2 \mathrm{a}$ & 2.66 & $*$ \\
\hline
\end{tabular}

Within a row, means with different letters differ at $P<0.05 . M=$ mean. $\mathrm{SEM}=$ standard error of the mean. Sig. = significant level. ${ }^{*} P<0.05$. ** $P<0.01$. *** $P<0.001$. NS $=$ not significant.

ment with Saffarzadeh et al. (1999) and Parissi et al. (2014) for Quercus brantii and Quercus ithaburensis respectively.

The CP content of acorns in the present study is in agreement with that obtained by Moujahed et al. (2007) and Parissi et al. (2014) for acorns from Quercus coccifera and Quercus ithaburensis respectively. It has to be noted that the CP content of kermes oak acorns was considerably higher than that found by Kaya and Kamalak (2012) for kermes oak.

Feed intake, dry-matter digestibility and animal performance are reduced if dietary crude protein is below $7 \%$ (McDonald et al., 2010), which results in energy-protein deficiency (Van Soest, 1994). Dietary CP requirements for maintenance of free-range goats, with a live weight of $40 \mathrm{~kg}$, ranges from 62 to $77 \mathrm{~g} \mathrm{~kg}^{-1}$ (NRC, 1981, 2000; Luo et al., 2004; Moore et al., 2004). According to this study, the average $\mathrm{CP}$ content in both kernel and hull were insufficient to meet these requirements.

Altitudinal zone significantly $(P<0.05)$ affected the cell wall contents of both kernel and hull (Table 2). The cell wall contents of both acorn kernel and hull were higher in the up-
Table 3. Mineral content of kermes oak kernel and hull in the tested altitudinal zones.

\begin{tabular}{|c|c|c|c|c|c|}
\hline \multirow[t]{2}{*}{ Parameter } & Lower & Middle & Upper & SEM & Sig. \\
\hline & \multicolumn{5}{|c|}{ Kernel } \\
\hline $\mathrm{Ca}\left(\mathrm{g} \mathrm{kg}^{-1}\right)$ & $0.66 \mathrm{ab}$ & $0.53 b$ & $0.80 \mathrm{a}$ & 0.056 & * \\
\hline $\mathrm{P}\left(\mathrm{g} \mathrm{kg}^{-1}\right)$ & $0.94 \mathrm{a}$ & $0.83 \mathrm{ab}$ & $0.71 b$ & 0.052 & $*$ \\
\hline Ca: P Ratio & $0.72 b$ & $0.65 b$ & $1.14 \mathrm{a}$ & 0.081 & * \\
\hline $\mathrm{K}\left(\mathrm{mg} \mathrm{kg}^{-1}\right)$ & $2.83 \mathrm{a}$ & $2.91 \mathrm{a}$ & $3.17 \mathrm{a}$ & 0.143 & NS \\
\hline $\operatorname{Mg}\left(\mathrm{mg} \mathrm{kg}^{-1}\right)$ & $0.35 \mathrm{a}$ & $0.39 a$ & $0.38 \mathrm{a}$ & 0.040 & NS \\
\hline $\mathrm{Fe}\left(\mathrm{mg} \mathrm{kg}^{-1}\right)$ & $10.69 \mathrm{a}$ & $8.97 b$ & $8.63 b$ & 0.477 & * \\
\hline $\mathrm{Cu}\left(\mathrm{mg} \mathrm{kg}^{-1}\right)$ & $2.80 \mathrm{a}$ & $2.20 \mathrm{ab}$ & $1.60 \mathrm{~b}$ & 0.252 & * \\
\hline $\operatorname{Mn}\left(\mathrm{mg} \mathrm{kg}^{-1}\right)$ & $17.49 \mathrm{a}$ & $18.68 \mathrm{a}$ & $19.78 \mathrm{a}$ & 1.290 & NS \\
\hline \multirow[t]{2}{*}{$\mathrm{Zn}\left(\mathrm{mg} \mathrm{kg}^{-1}\right)$} & $5.30 \mathrm{a}$ & $4.80 \mathrm{a}$ & $2.10 \mathrm{~b}$ & 0.693 & * \\
\hline & \multicolumn{5}{|c|}{ Hull } \\
\hline $\mathrm{Ca}\left(\mathrm{g} \mathrm{kg}^{-1}\right)$ & $1.41 \mathrm{a}$ & $1.28 \mathrm{a}$ & $1.55 \mathrm{a}$ & 0.097 & NS \\
\hline $\mathrm{P}\left(\mathrm{g} \mathrm{kg}^{-1}\right)$ & $0.35 \mathrm{a}$ & $0.38 \mathrm{a}$ & $0.31 \mathrm{a}$ & 0.036 & NS \\
\hline Ca: P Ratio & $4.05 \mathrm{ab}$ & $3.54 b$ & $5.27 \mathrm{a}$ & 0.499 & NS \\
\hline $\mathrm{K}\left(\mathrm{mg} \mathrm{kg}^{-1}\right)$ & $1.43 \mathrm{a}$ & $1.49 \mathrm{a}$ & $1.41 \mathrm{a}$ & 0.134 & NS \\
\hline $\operatorname{Mg}\left(\mathrm{mg} \mathrm{kg}^{-1}\right)$ & $0.37 \mathrm{a}$ & $0.34 \mathrm{a}$ & $0.32 \mathrm{a}$ & 0.049 & NS \\
\hline $\mathrm{Fe}\left(\mathrm{mg} \mathrm{kg}^{-1}\right)$ & $29.36 \mathrm{a}$ & $23.91 \mathrm{~b}$ & $22.41 \mathrm{~b}$ & 1.332 & * \\
\hline $\mathrm{Cu}\left(\mathrm{mg} \mathrm{kg}^{-1}\right)$ & $3.30 \mathrm{a}$ & $3.20 \mathrm{a}$ & $2.90 \mathrm{a}$ & 0.283 & NS \\
\hline $\operatorname{Mn}\left(\mathrm{mg} \mathrm{kg}^{-1}\right)$ & $21.89 \mathrm{a}$ & $20.85 a$ & $21.78 \mathrm{a}$ & 1.839 & NS \\
\hline $\mathrm{Zn}\left(\mathrm{mg} \mathrm{kg}^{-1}\right)$ & $5.90 \mathrm{a}$ & $3.79 b$ & $3.00 \mathrm{~b}$ & 0.694 & * \\
\hline
\end{tabular}

Within a row, means with different letters differ at $P<0.05 . M=$ mean. $\mathrm{SEM}=$ standard error of the mean. Sig. = significant level. ${ }^{*} P<0.05 .{ }^{* *} P<0.01$. *** $P<0.001$. NS $=$ not significant.

per zone $(P<0.05$; Table 2$)$ compared to lower and middle zones.

The fibre content of acorns is dependent on environmental characteristics and the stage of maturity (Moujahed et al., 2005). Thus, they decrease significantly with the maturity stage (Moujahed et al., 2005), probably due to an accumulation of reserves in the cotyledons (Bowersox and Ward, 1968).

According to Santini et al. (1992), the feed intake of goats can be reduced with an ADF content over $180 \mathrm{~g} \mathrm{~kg}^{-1}$ in drymatter forages. The average ADF content of hull was higher at all altitudinal zones. However, as the proportion of hull to whole acorn mass ranges from 0.17 to 0.23 (Table 1), it seems that goats that were fed only with kermes oak acorns could maximize their dry-matter intake (Table 4). Finally, the cell wall values were in agreement with the results of other studies carried out on oak acorns (Al Jassim et al., 1998; Kayouli and Buldgen, 2001; Parissi et al., 2014).

Dietary fibre plays a pivotal role in goat nutrition through its influence in and interaction with nutrient intake and digestion (Lu et al., 2005) and in milk-fat content (Schmidely et al., 1999). According to Buxton (1996), ideal NDF concentration ranges from 150 to $200 \mathrm{~g} \mathrm{NDF} \mathrm{kg}^{-1} \mathrm{DM}$ for fattening ruminants. For high-production lactating dairy goats, 180$200 \mathrm{~g} \mathrm{ADF} \mathrm{kg}^{-1} \mathrm{DM}$ or $410 \mathrm{~g} \mathrm{NDF} \mathrm{kg}^{-1} \mathrm{DM}$ is nutritionally 
Table 4. Estimated chemical composition and mineral contents of whole acorns based on the hull / kernel ratio of Table 1 .

\begin{tabular}{lrrrr}
\hline Parameter & Lower & Middle & Upper & Requirement* \\
\hline $\mathrm{CP}\left(\mathrm{g} \mathrm{kg}^{-1}\right)$ & 43.2 & 39.5 & 37.9 & 77 \\
$\mathrm{NDF}\left(\mathrm{g} \mathrm{kg}^{-1}\right)$ & 208.5 & 257.8 & 278.3 & - \\
$\mathrm{ADF}\left(\mathrm{g} \mathrm{kg}^{-1}\right)$ & 103.0 & 118.2 & 139.0 & - \\
$\mathrm{Ca}\left(\mathrm{g} \mathrm{kg}^{-1}\right)$ & 0.8 & 0.7 & 1.0 & 2.31 \\
$\mathrm{P}\left(\mathrm{g} \mathrm{kg}^{-1}\right)$ & 0.8 & 0.7 & 0.6 & 1.49 \\
$\mathrm{Ca}: \mathrm{P} \mathrm{Ratio}^{-1}$ & 1.0 & 1.0 & 1.7 & $1: 1-2: 1$ \\
$\mathrm{~K}\left(\mathrm{~g} \mathrm{~kg}^{-1}\right)$ & 2.6 & 2.6 & 2.8 & 2.5 \\
$\mathrm{Mg}\left(\mathrm{mg} \mathrm{kg}^{-1}\right)$ & 0.4 & 0.4 & 0.4 & 0.2 \\
$\mathrm{Fe}\left(\mathrm{mg} \mathrm{kg}^{-1}\right)$ & 13.9 & 12.1 & 11.8 & 50 \\
$\mathrm{Cu}\left(\mathrm{mg} \mathrm{kg}^{-1}\right)$ & 2.9 & 2.4 & 1.9 & 10 \\
$\mathrm{Mn}\left(\mathrm{mg} \mathrm{kg}^{-1}\right)$ & 18.2 & 19.1 & 20.2 & 50 \\
$\mathrm{Zn}\left(\mathrm{mg} \mathrm{kg}^{-1}\right)$ & 5.4 & 4.6 & 2.3 & 50 \\
\hline
\end{tabular}

* Required by mature goat with $40 \mathrm{~kg}$ live weight (NRC, 1981; Meschy, 2000).

adequate (Lu et al., 2005). Conversely, dietary NDF content higher than $600 \mathrm{~g} \mathrm{~kg}^{-1}$ decreased DM intake due to rumen capacity (Mertens, 1994). In the present study, even though NDF concentrations in the hull were greater than this threshold, it seems that the NDF content in overall acorn mass was lower than this value due to the low proportion of hull to overall acorn mass.

\subsection{Mineral composition}

Mineral concentrations depend on the part of the acorn in question. On average, mineral concentrations tended to be higher for the hull than for the kernel. In general, the concentrations of $\mathrm{Ca}, \mathrm{P}, \mathrm{Fe}, \mathrm{Zn}$, and $\mathrm{Cu}$ of the kernel were affected by the altitudinal zone. In particular, the significantly higher concentrations of $\mathrm{P}, \mathrm{Fe}, \mathrm{Cu}$, and $\mathrm{Zn}$ were recorded at the lower altitude, while a higher $\mathrm{Ca}$ value was recorded at the upper altitude (Table 3). Conversely, the altitudinal zone only had a significant impact $(P<0.05)$ on the $\mathrm{Fe}$ and $\mathrm{Zn}$ contents of the acorn hulls, with their concentration being significantly higher at the lower altitude (Table 3 ).

In order to compare the results with the nutrient requirements of a mature $40 \mathrm{~kg}$ live-weight goat, the chemical composition, mineral contents, and $\mathrm{Ca}: \mathrm{P}$ ratio of whole acorn fruit were estimated based on the kernel : hull ratio (Table 4).

Mature, $40 \mathrm{~kg}$ live-weight goats require about $2.31 \mathrm{Ca} \mathrm{g} \mathrm{kg}^{-1} \mathrm{DM}$ in their diets (NRC, 1981), although lower values were proposed by Meschy (2000). The results of this study suggest that $\mathrm{Ca}$ levels in whole acorn fruits (Table 4) would be insufficient to meet animal maintenance requirements. Phosphorus is an essential component for both plant and animal growth. The $\mathrm{P}$ requirements of mature goats are $1.49 \mathrm{~g} \mathrm{~kg}^{-1}$ in the DM of their diet (NRC, 1981). In this study, neither whole acorns nor the acorn components had sufficient $\mathrm{P}$ levels to meet the requirements. Nikolic
Table 5. Effect of altitudinal zone on nutrient and energy digestibility $\left(\mathrm{MJ} \mathrm{kg}^{-1}\right)$ of kermes oak kernel and hull.

\begin{tabular}{|c|c|c|c|c|c|}
\hline & Lower & Middle & Upper & SEM & Sig. \\
\hline & \multicolumn{5}{|c|}{ Kernel } \\
\hline IVDMD & $0.779 a$ & $0.667 \mathrm{~b}$ & $0.577 \mathrm{c}$ & 0.012 & $* * *$ \\
\hline IVNDFD & $0.645 \mathrm{a}$ & $0.583 b$ & $0.456 \mathrm{c}$ & 0.005 & $* * *$ \\
\hline $\mathrm{DE}\left(\mathrm{MJ} \mathrm{kg}^{-1}\right)$ & $12.93 \mathrm{a}$ & $10.86 \mathrm{~b}$ & $10.34 \mathrm{c}$ & 0.081 & $* * *$ \\
\hline $\mathrm{GE}\left(\mathrm{MJ} \mathrm{kg}^{-1}\right)$ & $18.94 \mathrm{~b}$ & $19.11 \mathrm{~b}$ & $19.62 \mathrm{a}$ & 0.121 & $* *$ \\
\hline \multicolumn{6}{|c|}{ Hull } \\
\hline IVDMD & $0.202 \mathrm{a}$ & $0.195 b$ & $0.183 \mathrm{c}$ & 0.0032 & ** \\
\hline IVNDFD & $0.008 \mathrm{a}$ & $0.006 \mathrm{~b}$ & $0.007 \mathrm{~b}$ & 0.0003 & * \\
\hline $\mathrm{DE}\left(\mathrm{MJ} \mathrm{kg}^{-1}\right)$ & $2.92 \mathrm{a}$ & $2.24 \mathrm{c}$ & $2.56 \mathrm{~b}$ & 0.076 & $* * *$ \\
\hline $\mathrm{GE}\left(\mathrm{MJ} \mathrm{kg}^{-1}\right)$ & $18.56 \mathrm{a}$ & $17.48 \mathrm{a}$ & $18.03 \mathrm{a}$ & 0.391 & NS \\
\hline
\end{tabular}

Within a row, means with different letters differ at $P<0.05$. $M=$ mean. $\mathrm{SEM}=$ standard error of the mean. Sig. $=$ significant level. ${ }^{*} P<0.05 .{ }^{* *} P<0.01$. *** $P<0.001$. NS $=$ not significant.

et al. (2006) also found lower values of $\mathrm{Ca}$ and $\mathrm{P}$ in oak (Quercus robur L.) acorns collected in Serbia.

Calcium and phosphorous are among the most abundant mineral elements for animal growth (McDonald et al., 2010). Absorption and utilization of $\mathrm{Ca}$ and $\mathrm{P}$ is dependent on the $\mathrm{Ca}: \mathrm{P}$ ratio in the diet and the presence of adequate amounts of vitamin D (McDonald et al., 2010; NRC, 2005). The optimum $\mathrm{Ca}: \mathrm{P}$ ratio to reduce functional disorders ranges from $1: 1$ to $2: 1$ (McDonald et al., 2010). The Ca: $\mathrm{P}$ ratio of the whole acorn fruit (Table 4) was at the optimal range in all altitudinal zones and was higher in the acorn hulls than in the kernels (Table 3) because the hulls had higher $\mathrm{Ca}$ and lower $\mathrm{P}$ concentrations than did the kernels, which led to higher $\mathrm{Ca}: \mathrm{P}$ ratios.

Mature goats require $50 \mathrm{~g} \mathrm{~kg}^{-1}$ of $\mathrm{Fe}$ in the DM of their diets (Meschy, 2000). Although Fe deficiency seldom occurs in grazing ruminants, it seems that the acorn kernels and hulls in all altitudinal zones had insufficient $\mathrm{Fe}$ amounts to meet the requirements.

The Mn content of the acorn components was also insufficient to meet the maintenance requirements of mature goats (50 $\mathrm{g} \mathrm{kg}^{-1}$ of DM; Meschy, 2000). This can result in a Mn deficiency with possible effects on skeletal development and reproductive performance, even though there is doubt regarding whether this deficiency arises under grazing conditions (McDonald et al., 2010).

All acorn components had $\mathrm{Zn}$ levels that did not exceed the requirement threshold (50 $\mathrm{g} \mathrm{kg}^{-1} \mathrm{DM}$; Meschy, 2000). Conversely, the acorn kernels and hulls had sufficient $\mathrm{K}$ and $\mathrm{Mg}$ to meet the requirements of mature goats $\left(2.5\right.$ and $0.2 \mathrm{~g} \mathrm{~kg}^{-1}$ respectively; Meschy, 2000).

Generally, variations in the mineral content of shrubs has been attributed to a dilution of minerals in the shrub biomass during growth, and subsequently to refining and resorption of minerals from the plants in autumn (Pugnaire and Chapin, 
Table 6. Coefficients associated with mean annual air temperature $\left(T_{\text {ave }}\right)$ and altitude above sea level $(Y)$ for significant* variance regression analysis of IVDMD, IVNDFD, and DE ( $\left.\mathrm{MJ} \mathrm{kg}^{-1} \mathrm{DM}\right)$ as dependent variables during growth of kermes oak acorns.

\begin{tabular}{llrr}
\hline & Regression equation & Adjusted & SE \\
& & $R^{2}$ & \\
\hline IVDMD $_{\text {kernel }}$ & $=0.354+0.024 T_{\text {ave }}$ & 0.917 & 0.0256 \\
IVDMD $_{\text {hull }}$ & $=0.157+0.003 T_{\text {ave }}-3 \times 10^{-6} Y$ & 0.518 & 0.0073 \\
IVNDFD $_{\text {kernel }}$ & $=0.264+0.022 T_{\text {ave }}$ & 0.926 & 0.0223 \\
IVNDFD $_{\text {hull }}$ & $=0.005+12 \times 10^{-5} T_{\text {ave }}-4 \times 10^{-8} Y$ & 0.074 & 0.0008 \\
DE $_{\text {kernel }}$ & $=2.979+0.517 T_{\text {ave }}+0.002 \times Y$ & 0.919 & 0.3346 \\
DE $_{\text {hull }}$ & $=-1.627+0.221 T_{\text {ave }}-0.002 \times Y$ & 0.493 & 0.2314 \\
\hline
\end{tabular}

* Significant at the 0.05 probability level.

1993) and the mobilization of minerals in the plant tissue due to the physiological functions of development (Sabate et al., 1992). Thus, mineral deficiencies seldom occur in grazing goats. This is because forages have adequate mineral concentrations and because of soil contamination of forages and direct soil consumption, which often provide excess quantities of dietary minerals (McDowell, 2003; McDonald et al., 2010).

\subsection{Nutrient digestibility}

In vitro DM digestibility, IVNDFD, and DE significantly differed $(P<0.05)$ among the altitudinal zones for both kernel and hull (Table 5). The IVDMD, IVNDFD, and DE of kernel and hull were higher $(P<0.05)$ in the lower zone than in the middle and upper zone (Table 5).

The DE values of the acorn components ranged from 10.34 to $12.93 \mathrm{MJ} \mathrm{kg}^{-1} \mathrm{DM}$ for the kernels and from 2.24 to $2.92 \mathrm{MJ} \mathrm{kg}^{-1} \mathrm{DM}$ for the hulls. The recommended daily intake of DE for goats with an average live weight of $40 \mathrm{~kg}$ and moderate muscular activity amounts to $10.25 \mathrm{MJ} \mathrm{kg}^{-1} \mathrm{DM}$ (NRC, 1981), although higher recommended levels have been reported (Villena and Pfister, 1990). It seems that only in the lower zone did the DE content of whole acorns exceed this threshold. According to McDonald et al. (2010), the reduced DE values can be attributed to the low IVDMD and $\mathrm{CP}$ contents of the acorns - as confirmed by the results of this study (Tables 2 and 5).

The acorn kernels generally had higher IVDMD values than the hulls did. This can be explained by the higher concentration of ADF and ADL in the hull compared to the kernel as the dry-matter lignification degree affects its digestibility (McDonald et al., 2010).

Furthermore, the lower digestibility of kernels in the middle and upper zones compared to the lower zone is probably a result of the higher cell wall concentrations. The low digestibility of NDF can dramatically impact dietary energy content and dry-matter intake (Oba and Allen, 1999). Van Soest (1994) stated that air temperature accelerates the maturation process, with dry-matter digestibility increasing with acorn maturity (Moujahed et al., 2005). Consequently, the overall decrease in IVDMD for the acorn kernels and hulls along the altitudinal zones was associated with high cell wall content.

In the present study, acorn kernel nutrient digestibility parameters (i.e. IVDMD, IVNDFD, DE) were positively correlated $(P<0.05)$ with mean monthly air temperature ( $r=0.961, r=0.965$, and $r=0.946$ respectively), which was negatively correlated with altitude a.s.1. $(r=-0.484$; $P<0.05)$. Thus, it can be stated that a higher nutritive value of kermes oak acorns at the same stage of maturity will be found at low-altitude growing sites.

Regression analyses quantified the relationships between the IVDMD, IVNDFD, and DE values of each acorn component (i.e. kernel, hull), and the mean annual air temperature and altitude above sea level were independent variables (Table 6). For the kernels, the mean annual air temperature was associated with IVDMD and IVNDFD. Indeed, a $1{ }^{\circ} \mathrm{C}$ rise in air temperature resulted in an increase of 0.024 for IVDMD and 0.022 for IVNDFD along the altitudinal zones.

Shrubs such as kermes oak are indispensable feed resources for goat nutrition in southern Europe. Their nutritional quality, however, is not always affected by their chemical composition due to the high presence of secondary compounds, especially lignin and tannins (Sallam et al., 2010). Additionally, it has to be noted that in vitro techniques have tended to underestimate the digestibility of shrub species (Van Soest, 1994) due to the presence of phenolic compounds (Rogosic et al., 2009), which reduce the enzymatic action (Nastis and Malechek, 1988). This reduction in nutrient digestibility parameters probably arises from increased levels of lignin or anti-nutritional factors such as tannins, as supported by Nastis and Malechek (1988), Van Soest (1994), and Sallam et al. (2010). Based on the results of this study, it is strongly recommended that goat shepherds prioritize feeding their livestock with acorns collected at the lower altitudinal zone due to these acorns' higher nutritive value. 


\section{Conclusions}

This study has provided evidence that the altitudinal gradient of a mountainside forms individual microclimates in each altitudinal zone, which directly affect kermes oak acorn nutritive value. Acorns growing under higher temperatures were found to have more digestible cell walls compared to acorns growing under lower temperatures due to the increased $\mathrm{CP}$ content and decreased cell wall content. However, the crude protein and mineral contents were insufficient to meet the maintenance requirements of grazing goats, and this indicates a potential risk of metabolic disorders. This finding suggests that protein and mineral supplementation is essential in order to avoid reduced productivity of goats. Nevertheless, kermes oak acorns, especially those collected from lower altitudes, could be considered cheap supplementary feed for the winter period.

Data availability. Data are available at https://www. researchgate.net/publication/316062013_Chemical_ composition_and_mineral_content_of_kermes_oak_kernel_ and_hull_on_Xirovouni_Mountain_North-western_Greece (doi:10.13140/RG.2.2.29333.73448).

Competing interests. The authors declare that they have no conflict of interest.

Edited by: M. Mielenz

Reviewed by: V. Vasileva and M. Sincik

\section{References}

Al Jassim, R. A. M., Ereifej, K., Shibli, R. A., and Abudabos, A.: Utilization of concentrate diets containing acorns (Quercus aegilops and Quercus coccifera) and urea by growing Awassi lambs, Small Ruminant Res., 29, 289-293, 1998.

AOAC: Official Methods of Analysis (Method 984.13), 16th Edn., Association of Official Analytical Chemists, Arlington, VA, USA, 1995.

AOAC: Official Methods of Analysis (Method 973.18), 16th Edn., Association of Official Analytical Chemists, Gaithersburg, MD, USA (3rd rev.), 1997.

AOAC: Official Methods of Analysis (Method 968.08), 16th Edn., Association of Official Analytical Chemists, Gaithersburg, MD, USA (5th rev.), 1999.

Bowersox, T. W. and Ward, W. W.: Auxin inhibition of epicormic shoots in white oak, Forest Sci., 14, 192-196, 1968.

Buxton, D. R.: Quality-related characteristics of forages as influenced by plant environment and agronomic factors, Anim. Feed Sci. Tech., 59, 37-49, 1996.

Chatzitheodoridis, F., Michailidis, A., and Theodossiou, G.: Comparative analysis of sheep - goat farming in a typical Greek island: Economy and environment, Appl. Econ. Policy Anal., 1, 191-200, 2007.
Dotsika, E., Lykoudis, S., and Poutoukis, D.: Spatial distribution of the isotopic composition of precipitation and spring water in Greece, Global Planet. Change, 71, 141-149, 2010.

Ferraz de Oliveira, M. I., Machado, M., and Cancela d'Abreu, M.: Acorn chemical composition depending on shedding date and Quercus species, Options Medit., 101, 229-234, 2012.

Hall, M. B. and Mertens, D. R.: In vitro fermentation vessel type and method alter fibre digestibility estimates, J. Dairy Sci., 91, 301-307, 2008.

HNMS: http://www.hnms.gr/hnms/greek/climatology/ climatology_region_diagrams_html?dr_city=Arta (last access: 7 January 2017), 2009.

Holechek, J. L., Pieper, R. D., and Herbel, C. H. (Eds.): Range Management Principles and Practices. Sixth Edition. Prentice-Hall Inc, Upper Saddle River, NJ, 456 pp., 2010.

Kaya, E. and Kamalak, A.: Potential nutritive value and condensed tannin contents of acorns from different oak species, Kafkas Univ. Vet. Fak., 18, 1061-1066, 2012.

Kayouli, C. and Buldgen, A.: Elevage durable dans les petites exploitations du Nord-ouest de la Tunisie, Faculté Universitaire des Sciences Agronomiques de Gembloux, Belgium, 2001.

Khalil, I. A. and Manan, F. (Eds.): Chemistry-One (Bio-Analytical Chemistry), 2nd Edn., National Book Foundation, Islamabad, Pakistan, 1990.

Lu, C. D., Kawas, J. R., and Mahgoub, O. G.: Fibre digestion and utilization in goats, Small Ruminant Res., 60, 45-52, 2005.

Luo, J., Goetsch, A. L., Nsahlai, I. V., Sahlu, T., Ferrell, C. L., Owens, F. N., Galyean, M. L., Moore, J. E., and Johnson, Z. B.: Metabolizable protein requirements for maintenance and growth of growing goats, Small Ruminant Res., 53, 309-326, 2004.

McDonald, P., Edwards, R. A., Greenhalgh, J. F. D., Morgan, C. A., Sinclair, L. A., and Wilkinson, R. G.: Animal Nutrition. 7th Edn., Pearson Education Limited, Harlow, UK, 712 pp., 2010.

McDowell, L. R. (Ed.): Minerals in Animal and Human Nutrition, 2nd Edn., Elsevier, the Netherlands, 2003.

Merouani, H., Apolinário, L. M., Almeida, M. H., and Pereira, J. S.: Morphological and physiological maturation of acorns of cork oak (Quercus suber L.), Seed Sci. Technol., 31, 111-124, 2003.

Mertens, D. R.: Regulation of forage intake, in: Forage Quality, Evaluation and Utilization, edited by: Fahey, G. C., American Society of Agronomy, Madison, WI, USA, 450-493, 1994.

Meschy, F.: Recent progress in the assessment of mineral requirements of goats, Livest. Prod. Sci., 64, 9-14, 2000.

Moore, J. E., Goetsch, A. L., Luo, J., Owens, F. N., Galyean, M. L., Johnson, Z. B., Sahlu, T., and Ferrell, C. L.: Prediction of fecal crude protein excretion of goats, Small Ruminant Res., 53, 275-292, 2004.

Moujahed, N., Ben Mustafa, C., and Kayouli, C.: Effect of maturity stage on chemical composition, in sacco degradation and in vitro fermentation of acorn (Quercus coccifera L.), Options Medit., 67, 413-417, 2003.

Moujahed, N., Ben Mustafa, C., and Kayouli, C.: Effect of barley replacement by acorns (Quercus coccifera $L$.) as energy supplement on in vitro fermentation, Options Medit., 74, 183-187, 2005.

Moujahed, N., Moujahed-Raach, A., Ben Mustapha, C., Bel Heni, H., and Kayouli, C.: Effects of nitrogen supplementation of acorns (Quercus coccifera) on in vitro fermentation, intake and digestion by lambs, Livestock Res. Rural. Dev., 19, \#54, 2007. 
Nastis, A. S.: Nutritive value of oak browse (Quercus coccifera L.) foliage for goats at various phenological stages, Dissertation, Aristotle University of Thessaloniki, Greece, 1982.

Nastis, A. S. and Malechek, J. C.: Estimating digestibility of oak browse diets for goats by in vitro techniques, J. Range Manage., 41, 255-258, 1988.

Nieto, R., Rivera, M., Garcia, M. A., and Aguilera, J. F.: Amino acid availability and energy value of acorn in the Iberian pig, Livest. Prod Sci., 77, 227-239, 2002.

Nikolic, N., Orlovic, S., Krstic, B., and Kevrsan, Ž.: Variability of acorn nutrient concentrations in pedunculate oak (Quercus robur L.) genotypes, J. For. Sci., 52, 51-60, 2006.

NRC: Nutrient Requirements of Goats: Angora, Dairy, and Meat Goats in Temperate and Tropical Countries, National Academy Press, Washington, DC, 1981.

NRC: Nutrient Requirements of Beef Cattle, Update 2000. National Academy Press, Washington, DC, 2000.

NRC: Mineral Tolerance of Animals, 2nd revised Edn., National Academy Press, Washington, DC, USA, 2005.

Oba, M. and Allen, M. S.: Evaluation of the importance of the digestibility of neutral detergent fibre from forage: effects on dry matter intake and milk yield of dairy cows, J. Dairy Sci., 82, 589-596, 1999.

Papachristou, T. G., Dziba, L. E., and Provenza, F.D .: Foraging ecology of goats and sheep on wooded rangelands, Small Ruminant Res., 59, 141-156, 2005.

Parissi, Z. M., Kyriazopoulos, A. P., and Pantera, A.: Chemical composition of Quercus ithaburensis subsp. macrolepis (Kotschy) Hedge \& Yaltirik acorns from different regions, in: Rangelands and Animal Farming: Research and Development, Proceedings of the 8th Panhellenic Rangeland Congress, 253257, 2014

Pons, J. and Pausas, J. G.: The coexistence of acorns with different maturation patterns explains acorn production variability in cork oak, Oecologia, 169, 723-731, 2012.

Pugnaire, F. I. and Chapin, F. S.: Controls over nutrient resorption from leaves of evergreen Mediterranean species, Ecology, 74, 124-129, 1993.

Rogosic, J., Pfister, J. A., Provenza, F. D., and Pavlicevic, J.: The effect of polyethylene glycol on intake of Mediterranean shrubs by sheep and goats, J. Anim. Sci., 86, 3491-3496, 2009.

Roukos, C.: Seasonal and altitudinal variations in nutritional quality of kermes oak (Quercus coccifera L.) in northwest Greece, Bulg. J. Agric. Sci., 22, 804-814, 2016.
Roukos, C., Papanikolaou, K., Mountousis, I., Kandrelis, S., and Chatzitheodoridis, F.: Soil properties variations in relation to plant community and altitudinal zone in the rangelands of Epirus, Greece, Bulg. J. Agric. Sci., 17, 806-815, 2011.

Sabaté, S., Calvet, S., and Gràcia, C. A.: Preliminary results of fertilization irrigation experiments in a Quercus ilex L. ecosystem at Prades Mountains in Tarragona (NE Spain) in relation to leaves and twigs, Vegetatio, 99-100, 283-287, 1992.

Saffarzadeh, A., Vincze, L., and Csapo, J.: Determination of the chemical composition of acorn (Quercus brantii), Pistacia atlantica, Pistacia khinjuk seeds as non-conventional feedstuffs, Acta Agr. Kaposvariensis, 3, 59-69, 1999.

Sallam, S. M. A., Bueno, I. C. S., Godoy, P. B., Nozella, E. F., Vitti, S., Silber, D. M., and Abdalla, A. L.: Ruminal fermentation and tannins bioactivity of some browses using a semi-automated gas production technique, Trop. Subtrop. Agroecosys., 12, 1-10, 2010.

Santini, F. J., Lu, C. D., Potchoiba, M. J., Fernandez, J. M., and Coleman, S. W.: Dietary fibre and milk yield, mastication, digestion and rate of passage in high Alpine goats fed alfalfa hay, J. Dairy Sci., 75, 209-219, 1992.

Schmidely, P., Lloret-Pujol, M., Bas, P., Rouzeau, A., and Sauvant, D.: Influence of feed intake and source of dietary carbohydrate on milk yield and composition, nitrogen balance, and plasma constituents of lactating goats, J. Dairy Sci., 82, 747-756, 1999.

Steel, R. G. and Torrie, J. H.: Principles and Procedures of Statistics. McGraw-Hill Book Co., New York, NY, USA, 1980.

Tsiouvaras, C. N.: Ecology and Management of kermes oak (Quercus coccifera L.) shrublands in Greece: A review, J. Range Manage., 40, 542-546, 1987.

Van Soest, P. J. (Ed): Nutritional ecology of the ruminant, Cornell University Press, New York, 1994.

Van Soest, P. J., Robertson, J. B., and Lewis, B. A.: Methods for dietary fibre, neutral detergent fibre, and nonstarch polysaccharides in relation to animal nutrition, J. Dairy Sci., 74, 3583-3597, 1991.

Vázquez, F., Doncel, E., and Ramos, S.: Variaciones de calidad en la bellota, Solo Cerdo Ibérico, 6, 75-80, 2001.

Villena, F., and Pfister, J.A.: Sand shinnery oak as forage for Angora and Spanish goats, J. Range Manage., 43, 116-122, 1990.

Vogel, K. P., Pedersen, J. F., Masterson, S. D., and Toy, J. J.: Evaluation of a filter bag system for NDF. ADF and IVDMD forage analysis, Crop Sci., 39, 276-279, 1999.

Zervas, G.: Quantifying and optimizing grazing regimes in Greek mountain systems, J. Appl. Ecol., 35, 983-986, 1998. 